\title{
Design and Effective Operation of Double Winding Synchronous Reluctance Motor
}

\author{
V.Chandrasekaran and T.Manigandan
}

\begin{abstract}
Reluctance motors are generally employed in synthetic fibre industry, glass making machinery and textile industry where the speed is almost constant. The power factor and efficiency of reluctance motor ranges between 0.35 to 0.5 and $55 \%$ to $75 \%$ respectively. The product of power factor and efficiency is between 0.25 and 0.32 . An attempt is made in this paper to improve the efficiency and power factor of reluctance motor. A $3 \mathbf{k W}$, 415V, 1500 rpm, Double Winding Synchronous Reluctance Motor (DWSyRM) has been designed, fabricated and tested. The stator consists of two sets of three phase winding in the same core. Saliency is made in the squirrel cage rotor by removing the set of rotor teeth alternatively. When a three phase supply is given to the stator winding, a revolving magnetic field of constant magnitude is developed in the air gap. Rotor poles are pulled into synchronism by reluctance torque. Out of two windings in the stator, one winding is used to meet the mechanical load while a three phase emf induced in the second winding works as an Induction alternator (IA), to which a single phase or small three phase load can be connected. Since the machine runs at synchronous speed the terminal voltage at the secondary winding is almost maintained at a constant. Both the windings can be loaded simultaneously. Machine has to be operated at its maximum capacity for the given no load losses, to achieve better efficiency. Load tests with various combinations of electrical and mechanical loads have been conducted. Experiment results prove the improvement in the efficiency and power factor to a great extent compared to Reluctance motor.
\end{abstract}

Index Terms-Double Winding Synchronous Reluctance Motor (DWSyRM), Induction alternator, Efficiency, Power factor improvement

\section{INTRODUCTION}

The efficiency and power factor are the important targets to be reached in both industrial and commercial applications of electric drives. There are various methods to improve and optimize the efficiency of induction motor. Optimal control is the one of the techniques to obtain optimum efficiency which covers the broad approaches namely, loss model control (LMC) and search control (SC). Optimal design covers the design modifications of materials and construction in order to optimize efficiency of the motor and differential evolution are some techniques to optimize the efficiency [1]. In the

Manucript received December 19, 2010; revised May 2, 2011. conventional induction motor, only single output is available. The efficiency and power factor of the induction motor is depending on the load torque. Normally over rated motors are employed due to factor of safety and design specifications, and hence, induction motors are operated lower than their rated capacity. DWIM is developed to overcome the drawbacks of conventional induction motor in which two outputs are available. DWIM can be operated either in maximum efficiency mode or power balancing mode by using appropriate control circuit [19]. There is a voltage drop in the second stator winding due to the reduction in speed when the motor is loaded and this leads to poor voltage regulation. In order to improve the performance of DWIM, a new Double Winding Synchronous Reluctance Motor (DWSyRM) is suggested in this paper and the main motivation for this paper is to improve the efficiency and power factor of Double Winding Synchronous Reluctance Motor (DWSyRM). Double winding induction machine consists of two stator windings and a cage rotor. One stator winding acts as a motor and the other as a generator. By controlling the voltage supplied to the secondary or the generator winding, the rotor speed can be adjusted. The machine has a similar speed control characteristics to that of a slip-ring induction motor equipped with the rotor energy recovery scheme [20]. Introduction of double winding induction machine was suggested and implemented in the year 1930 for turbine alternators. In a Double Winding Induction Motor, When one of the windings is connected to a three phase supply, a revolving magnetic filed of constant magnitude is developed in the air gap. The same filed is utilized by both the stator windings to work as induction motor to meet mechanical load while, a three phase EMF is induced in the second set of winding [4].

The occurrence of circulating harmonic current common to traditional dual stator machine is completely eliminated by the dissimilar number of pole winding. The two stator windings can have different number of poles. Power is supplied to the two windings by two separate variable frequency inverter drives to provide two independently controllable torque components. At low speeds, the power supplied to one of the windings can produce torque which opposes the torque from the power applied to the other winding, so that very low speed and standstill operation can be achieved. At higher operating speeds, power is supplied to both the windings, so that the torques from the two windings is added up [5]. Dual stator induction motor suggested for energy conservation consists of two sets of RUN windings. The main RUN winding is energized to have sufficient MMF in order to produce sufficient magnetic flux and to operate the motor at light loads with good power factor. When the 
shaft load is increased in this machine, $10-30 \%$ reduced power is applied to the second set of RUN winding and hence, the power consumed due to eddy currents, copper losses and poor power factor are considerably reduced [8].

High dynamic torque regulation and efficiency optimization of the synchronous reluctance motor (SynRM) can be obtained using a nonlinear controller with input-output feedback linearization. Since nonlinear controller directly regulates the torque by selecting the product of d-and q-axes torque currents as one of the output variables, the nonlinear and cross-coupling torque of $\mathrm{d}$-and q-axes currents and the terminal currents can be eliminated [11]. The performance of IPMSM, SynRM and IM are compared. It was found that the IPMSM (Interior Permanent Magnet Synchronous Motor) was superior in terms of efficiency and SynRM costs the lowest and its efficiency was higher than a typical IM because of its rotor copper losses [13]. A stator-flux-oriented control scheme can be used in a synchronous machine without a position sensor at medium and high electrical frequencies. For a given speed and torque, power losses in the machine are given as a function of stator flux. The optimal flux value can be found by using a one-dimensional optimization algorithm. By means of vector torque controller, the machine can be operated to achieve maximum efficiency over a wide range of power and rotational speed [14].

From the above discussions, the availability of several of types of Synchronous Reluctance Motors and their speed control methods are learnt. Double winding induction motors are popular for energy conservation and speed control applications. In this paper, the main motivation is to improve the efficiency and power factor of DWSyRM by its design modification and efficient operation.

\section{MACHINE MODEL}

The DWSyRM consists of a stator with two sets of identical windings and a cage rotor. The optimum design of an induction motor can be suggested using simulated annealing algorithm considering the starting torque, efficiency and power factor. A nonlinear multivariable programming has been formulated to meet the above requirements [10].

\section{A. Representation of the Proposed Scheme}

The stator windings of a double winding induction motor can be arranged with different shift angles between them. In double winding induction motor, shift angle of 60 degrees or zero degrees are the best choice [6]. In the proposed model, to obtain optimum utilization, both the windings are placed with zero degree phase angle displacement between them. As a proof for the discussion, a $3 \mathrm{~kW}, 415 \mathrm{~V}, 4$-pole, 3-phase Squirrel Cage Double Winding Synchronous Reluctance Motor has been designed, fabricated and tested. Representation of Double Winding Synchronous Reluctance Motor is shown in Figure. 1.

\section{B. Design Considerations}

The main feature of a segmented type synchronous reluctance motor is the flux barrier. The $\mathrm{d}$, $\mathrm{q}$ inductance difference and saliency ratio are identified as they are related to torque and power factor [2]. The design of the Double Winding Synchronous Reluctance motor is affected by various constraints such as thermal limit, overload capacity and utility of stator slots. The energy conserving double winding Synchronous Reluctance motor is ideal to be used for low power operations due to the limitation in thermal insulation value. The value of air gap flux density is large, which determines large overload capacity. The use of semi-enclosed slots results in silent operation. Slot utility factor for the designed DWSyRM motor is about $43.3 \%$ where as for conventional induction motor, it is about $25 \%$. $\mathrm{L} / \tau$ ratio of designed machine is approximately unity.
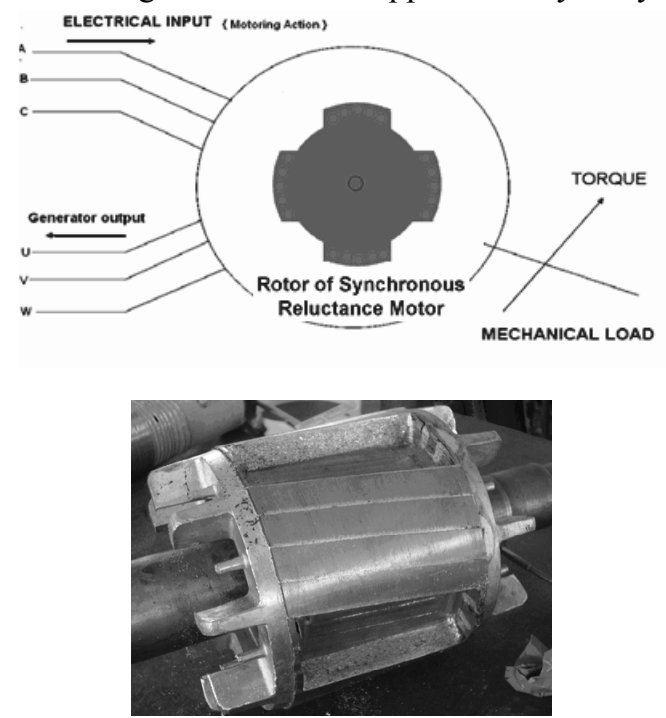

Figure.1. Double Winding Synchronous Reluctance motor

\section{Design of DWIM machine}

Number of poles $=4$

Synchronous speed $=1500 \mathrm{rpm}$

Diameter of the core $=0.139 \mathrm{~m}$

Length of the core $=0.11 \mathrm{~m}$

Number of turns per phase $=240$ with 36 SWG.

Both the stator windings are of identical nature. Current density chosen is $7.5 \mathrm{~A} / \mathrm{mm}^{2}$

Electrical loading $=21000 \mathrm{~A} / \mathrm{m}^{2}$

Magnetic loading $=0.44 \mathrm{wb} / \mathrm{m}^{2}$

\section{EXPERIMENTAL INVESTIGATIONS}

The various direct and indirect methods of testing of induction motor are available. Numerical method analysis using the current and flux density waveforms is the one of the methods to calculate iron losses of an electric machine. This method of calculation is based on finite element analysis and is suitable for any synchronous and DC machines [3]. Efficiency of a synchronous machine over its wide range of operation can be improved by compensating the core loss currents. Control scheme using a vector controller is used to compensate core loss currents of the machine. Inductance ripple in the machine is estimated and incorporated in a machine model using sing a direct torque ripple measurements [7]. Synthetic loading technique is an another method of rapid full load efficiency evaluation of three phase induction motors by using the digital signal processor (DSP) controlled high switching frequency power electronic inverter which synthetically loads the induction machine 
without the need to connect a load to the shaft. This method can also directly quantify rotational losses of the induction motor under test [9].In order to operate the synchronous reluctance machine at very high speeds, bonded sections of ferromagnetic and nonmagnetic steel core are provided in the rotor section. Finite-element code has been developed in MATLAB which measures the steady-state eddy currents and losses in the rotor. In this machine, an efficiency of $91 \%$ at a $10-\mathrm{kW} 10000-\mathrm{r} / \mathrm{min}$ operating point, and rotor losses less than $0.5 \%$ of input power can be obtained [12]. The Reluctance machine performance is investigated using the $d-q$ rotor reference frame equations derived in space-vector model obtained by applying the concept of winding functions. Core loss and saturation components are also considered for the dynamic model. Out of two windings, one winding is connected to the supply and the other fed with a balanced capacitor. In this machine, the developed torque is superior to a brushless doubly-fed reluctance machine [16]. A mathematical model of the SynRM with core loss component has been developed. In order to obtain maximum efficiency, a grey sliding mode controller is used to reject the uncertain bounded disturbances and parameter variations. The grey sliding mode controller is implemented using dSPACE DS1 102 processor board [17]. The saliency of a synchronous reluctance motor can be improved with a slit rotor. The stator teeth are divided and are made of powder magnetic core. In the rotor, stainless sheets are inserted along with soft magnetic metal sheets with adhesive to strengthen the rotors and thereby saliency ratio is improved. Power factor about 0.78 and torque of 1.6 times the conventional motor can be achieved [15]. Optimum efficiency operation of a synchronous reluctance motor can be made possible by minimizing the losses considering both voltage and current constraints. A high-performance current control scheme is suggested using the simulated currents in which the current sensors are eliminated [18]. Experimental set up for conducting the various testing is shown in the Figure.2.

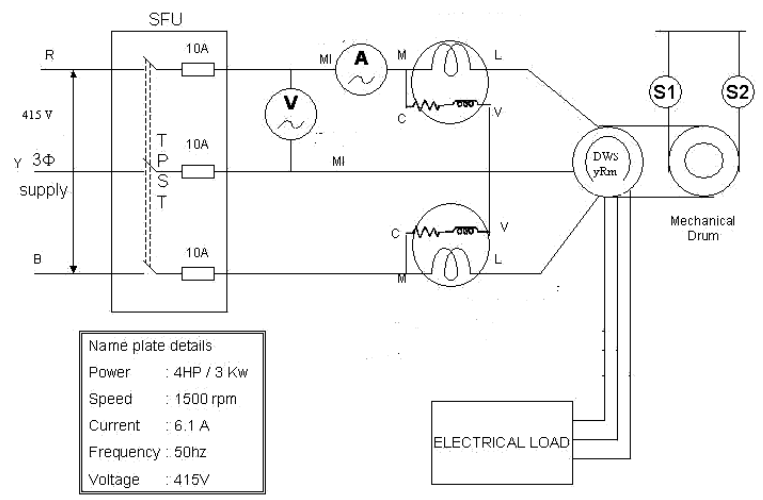

Figure 2. Experimental Setup

The following testing arrangements are used for testing the DWSyRM.

1) Conventional Mechanical load test: Using brake drum arrangement, load test has been carried out in both the windings considering each winding separately to analyze the performance of the machine.

2) Mechanical and Electrical load test: Mechanical load is applied by means of a brake drum arrangement and an electrical load is applied using three phase loading rheostat in the second set of stator winding.

In order to study the performance of the designed DWSyRM, testing was carried out with the various combinations of electrical and mechanical loads. The following tables show the details of observation.

\section{TABLE I. CONVENTIONAL BRAKE TEST}

\begin{tabular}{|c|c|c|c|c|c|c|c|}
\hline SNO & $\begin{array}{l}\text { Input } \\
\text { Voltze } \\
\text { in Volts } \\
415 \\
\end{array}$ & $\begin{array}{l}\text { Irqut } \\
\text { Cument in } \\
\text { Arms } \\
2.0\end{array}$ & $\begin{array}{l}\text { Irqut } \\
\text { Power } \\
\text { in Watts } \\
680\end{array}$ & $\begin{array}{c}\text { Torque } \\
\text { in } \mathrm{Hm} \\
0 \\
0\end{array}$ & $\begin{array}{l}\text { Mecharical } \\
\text { output in } \\
\text { Watts } \\
0\end{array}$ & 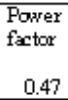 & $\begin{array}{l}\% \\
\text { Efficiency }\end{array}$ \\
\hline 2 & 415 & 2.5 & 980 & 3.4 & 534 & 0.55 & 54.5 \\
\hline 3 & 415 & 3.0 & 1200 & 5.0 & 785 & 0.59 & 61.4 \\
\hline 4 & 415 & 3.5 & 1520 & 6.0 & 943 & 0.6 & 62.0 \\
\hline 5 & 415 & 4.0 & 1740 & 7.0 & 1100 & 0.61 & 63.2 \\
\hline 6 & 415 & 4.5 & 1900 & 7.6 & 1194 & 0.58 & 62.8 \\
\hline 7 & 415 & 5.0 & 2000 & 8.4 & 1320 & 0.58 & 63.4 \\
\hline 8 & 415 & 5.5 & 2000 & 9.0 & 1414 & 0.56 & 64.2 \\
\hline
\end{tabular}

TABLE.II. MECHANICAL LOAD WITH 1 A ELECTRICAL LOAD

\begin{tabular}{|c|c|c|c|c|c|c|c|c|c|}
\hline S.No & $\begin{array}{l}\text { Input } \\
\text { V oltage } \\
\text { in } \\
\text { Volts }\end{array}$ & $\begin{array}{l}\text { Irput } \\
\text { Current } \\
\text { in } \\
\text { Amps }\end{array}$ & \begin{tabular}{|l|} 
Input \\
Power \\
in \\
Watts \\
\end{tabular} & \begin{tabular}{|l} 
Torque \\
in Nm
\end{tabular} & $\begin{array}{l}\text { Mech } \\
\text { Output } \\
\text { in } \\
\text { Watts }\end{array}$ & $\begin{array}{l}\text { Electrical } \\
\text { Output in } \\
\text { Watts }\end{array}$ & $\begin{array}{l}\text { Total } \\
\text { output } \\
\text { in } \\
\text { Watts }\end{array}$ & \begin{tabular}{|l|}
$\%$ \\
Efficiency
\end{tabular} & $\begin{array}{l}\text { Power } \\
\text { Factor }\end{array}$ \\
\hline 1 & 410 & 2.1 & 1040 & 0.0 & 0 & 680 & 680 & 65.4 & 0.7 \\
\hline 2 & 410 & 2.5 & 1360 & 2.2 & 346 & 680 & 1026 & 75.4 & 0.76 \\
\hline 3 & 410 & 3.0 & 1640 & 4.0 & 628 & 680 & 1308 & 79.7 & 0.77 \\
\hline 4 & 410 & 3.5 & 1960 & 5.6 & 880 & 680 & 1560 & 79.6 & 0.79 \\
\hline 5 & 410 & 4.0 & 2200 & 6.0 & 942 & 680 & 1622 & 73.7 & 0.77 \\
\hline 6 & 410 & 4.5 & 2380 & 6.8 & 1068 & 680 & 1748 & 73.4 & 0.74 \\
\hline 7 & 410 & 5.0 & 2540 & 7.6 & 1194 & 680 & 1874 & 73.7 & 0.71 \\
\hline 8 & 410 & 5.5 & 2680 & 8.0 & 1257 & 680 & 1937 & 72.2 & 0.69 \\
\hline
\end{tabular}

TABLE.III. MECHANICAL LOAD WITH 2 A ELECTRICAL LOAD

\begin{tabular}{|c|c|c|c|c|c|c|c|c|c|}
\hline S.No & $\begin{array}{l}\text { Input } \\
\text { Voltage } \\
\text { in } \\
\text { Volts }\end{array}$ & $\begin{array}{l}\text { Input } \\
\text { Current } \\
\text { in } \\
\text { Amps }\end{array}$ & \begin{tabular}{|l|} 
Input \\
Power \\
in \\
Watts
\end{tabular} & $\begin{array}{l}\text { Torque } \\
\text { in Nm }\end{array}$ & \begin{tabular}{|l} 
Mech \\
Output \\
in \\
Watts
\end{tabular} & $\begin{array}{l}\text { Electrical } \\
\text { Output in } \\
\text { Watts }\end{array}$ & \begin{tabular}{|l|} 
Total \\
output \\
in \\
Watts
\end{tabular} & $\begin{array}{l}\% \\
\text { Efficiency }\end{array}$ & $\begin{array}{l}\text { Power } \\
\text { Factor }\end{array}$ \\
\hline 1 & 410 & 2.8 & 1720 & 0.0 & 0 & 1340 & 1340 & 78 & 0.87 \\
\hline 2 & 410 & 3.0 & 1840 & 0.8 & 126 & 1340 & 1466 & 79.7 & 0.86 \\
\hline 3 & 410 & 3.5 & 2300 & 3.0 & 471 & 1340 & \begin{tabular}{|l|l}
1811 \\
\end{tabular} & 78.7 & 0.93 \\
\hline 4 & 410 & 4.0 & \begin{tabular}{|l|l}
2480 \\
\end{tabular} & 4.4 & 691 & 1340 & 2031 & 81.9 & 0.87 \\
\hline 5 & 410 & 4.5 & \begin{tabular}{|l|l}
2720 \\
\end{tabular} & 5.6 & 880 & 1340 & 2219 & 81.6 & 0.85 \\
\hline 6 & 410 & 5.0 & 2920 & 6.6 & 1037 & 1340 & 2377 & 81.4 & 0.82 \\
\hline 7 & 410 & 5.5 & 3140 & 7.0 & 1099. & 1340 & 2439 & 77.7 & 0.8 \\
\hline
\end{tabular}

TABLE.IV. MECHANICAL LOAD WITH 3 A ELECTRICAL LOAD

\begin{tabular}{|c|c|c|c|c|c|c|c|c|c|}
\hline S.No & $\begin{array}{l}\text { Input } \\
\text { V oltage } \\
\text { in } \\
\text { Volts }\end{array}$ & $\begin{array}{l}\text { Input } \\
\text { Current } \\
\text { in } \\
\text { Amps }\end{array}$ & $\begin{array}{l}\text { Input } \\
\text { Power } \\
\text { in } \\
\text { Watts }\end{array}$ & $\begin{array}{l}\text { Tor que } \\
\text { in Nm }\end{array}$ & $\begin{array}{l}\text { Mech } \\
\text { Output } \\
\text { in } \\
\text { Watts }\end{array}$ & $\begin{array}{l}\text { Electrical } \\
\text { Output in } \\
\text { Watts }\end{array}$ & $\begin{array}{l}\text { Total } \\
\text { output } \\
\text { in } \\
\text { Watts }\end{array}$ & $\begin{array}{l}\text { \% } \\
\text { Efficiency }\end{array}$ & $\begin{array}{l}\text { Power } \\
\text { Factor }\end{array}$ \\
\hline 1 & 410 & 3.4 & 2260 & 0 & 0 & 1820 & 1820 & 80.5 & 0.94 \\
2 & 410 & 4.0 & 2640 & 2 & 314 & 1820 & 2134 & 80.8 & 0.93 \\
3 & 410 & 4.5 & 2940 & 3.8 & 597 & 1820 & 2417 & 82.2 & 0.92 \\
4 & 410 & 5.0 & 3180 & 5.4 & 848 & 1820 & 2668 & 82.5 & 0.90 \\
5 & 410 & 5.5 & 3420 & 6 & 942 & 1820 & 2762 & 80.7 & 0.88 \\
\hline
\end{tabular}

TABLE.V. MECHANICAL LOAD WITH 4 A ELECTRICAL LOAD

\begin{tabular}{|c|c|c|c|c|c|c|c|c|c|}
\hline S.No & $\begin{array}{l}\text { Input } \\
\text { Voltage } \\
\text { in } \\
\text { Volts }\end{array}$ & $\begin{array}{l}\text { Input } \\
\text { Current } \\
\text { in } \\
\text { Amps }\end{array}$ & \begin{tabular}{l|} 
Input \\
Power \\
in \\
Watts
\end{tabular} & $\begin{array}{l}\text { Torque } \\
\text { in } \mathrm{Nm}\end{array}$ & $\begin{array}{l}\text { Mech } \\
\text { Output } \\
\text { in } \\
\text { Watts }\end{array}$ & $\begin{array}{l}\text { Electrical } \\
\text { Output in } \\
\text { Watts }\end{array}$ & \begin{tabular}{|l|} 
Total \\
output \\
in \\
Watts
\end{tabular} & $\begin{array}{l}\% \\
\text { Efficiency }\end{array}$ & \begin{tabular}{|l|} 
Power \\
Factor
\end{tabular} \\
\hline 1 & 410 & 4.2 & 2880 & 0 & 0 & 2280 & 2280 & 79.1 & 0.965 \\
\hline 2 & 410 & 4.5 & 3100 & 1 & 157 & 2280 & 2437 & 78.6 & 0.97 \\
\hline 3 & 410 & 5 & 3400 & 3.4 & 534 & 2280 & 2814 & 82.7 & 0.96 \\
\hline 4 & 410 & 5.5 & 3680 & 4.2 & 660 & 2280 & 2940 & 79.8 & 0.94 \\
\hline
\end{tabular}

TABLE.VI. CONSTANT MECHANICAL LOAD WITH VARIABLE ELECTRICAL LOAD

\begin{tabular}{|c|c|c|c|c|c|c|c|c|c|}
\hline S.No & Input & Input & Input & Tor que & Mech & Electrical & Total & $\%$ & Power \\
& Voltage & Current & Power & in Nm & Output & Output in & output \\
in & in & & in & Watts & in & & & \\
& in & in & inciency & Factor \\
& Volts & Amps & Watts & & Watts & & Watts & & \\
1 & 415 & 2 & 700 & 22 & 346 & 0 & 346 & 49.4 & 0.49 \\
2 & 415 & 2.3 & 1140 & 22 & 346 & 380 & 726 & 63.6 & 0.69 \\
3 & 415 & 2.6 & 1480 & 22 & 346 & 720 & 1066 & 72 & 0.79 \\
4 & 415 & 3 & 1820 & 22 & 346 & 1080 & 1426 & 78.3 & 0.84 \\
\hline 5 & 415 & 3.3 & 2140 & 22 & 346 & 1380 & 1726 & 80.6 & 0.90 \\
\hline 6 & 415 & 3.7 & 2480 & 22 & 346 & 1680 & 2026 & 81.6 & 0.93 \\
\hline 7 & 415 & 4.3 & 3040 & 22 & 346 & 2160 & 2506 & 82.4 & 0.98 \\
\hline 8 & 415 & 4.7 & 3360 & 22 & 346 & 2400 & 2746 & 81.7 & 0.99 \\
\hline 9 & 415 & 5.2 & 3680 & 22 & 346 & 2640 & 2986 & 81.1 & 0.98 \\
\hline 10 & 415 & 5.6 & 3980 & 22 & 346 & 2860 & 3206 & 80.5 & 0.98 \\
\hline 11 & 415 & 5.8 & 4160 & 22 & 346 & 3040 & 3386 & 81.3 & 0.99 \\
\hline
\end{tabular}


TABLE VII. EFFICIENCY AND POWER FACTOR COMPARISON FOR CONSTANT MECHANICAL LOADING WITH VARIABLE ELECTRICAL LOAD

\begin{tabular}{|c|c|c|c|c|}
\hline S.No & $\begin{array}{c}\text { Mechanical } \\
\text { loading in } \\
\text { Amps }\end{array}$ & $\begin{array}{c}\text { Electric al loading } \\
\text { in Amps }\end{array}$ & $\begin{array}{c}\% \\
\text { Efficiency }\end{array}$ & $\begin{array}{c}\text { Power } \\
\text { Factor }\end{array}$ \\
\hline 1 & 4.5 & - & 81.2 & 0.63 \\
\hline 2 & 4.5 & 1.0 & 84.0 & 0.65 \\
\hline 3 & 4.5 & 1.5 & 86.5 & 0.65 \\
\hline 4 & 4.5 & 2.0 & 87.0 & 0.82 \\
\hline 5 & 4.5 & 3.0 & 87.5 & 0.85 \\
\hline 6 & 4.5 & 4.0 & 90.9 & 0.91 \\
\hline
\end{tabular}

TABLE VIII. EFFICIENCY AND POWER FACTOR COMPARISON FOR CONSTANT MECHANICAL LOADING WITH VARIABLE ELECTRICAL LOAD

\begin{tabular}{|c|c|c|c|c|}
\hline S.No & $\begin{array}{c}\text { Mechanical } \\
\text { loading in } \\
\text { Amps }\end{array}$ & $\begin{array}{c}\text { Electric al loading } \\
\text { in Amps }\end{array}$ & $\begin{array}{c}\% \\
\text { Efficiency }\end{array}$ & $\begin{array}{c}\text { Power } \\
\text { Factor }\end{array}$ \\
\hline 1 & 5.0 & - & 63.4 & 0.58 \\
\hline 2 & 5.0 & 1.0 & 73.7 & 0.71 \\
\hline 3 & 5.0 & 2.0 & 81.4 & 0.82 \\
\hline 4 & 5.0 & 3.0 & 82.5 & 0.90 \\
5 & 50 & 40 & 82.7 & 0.96 \\
\hline
\end{tabular}

TABLE IX. EFFICIENCY AND POWER FACTOR COMPARISON DWIM AND DWSYRM

\begin{tabular}{|l|l|l|l|l|l|l|}
\hline S.No & $\begin{array}{l}\text { Mechanical } \\
\text { loading in } \\
\text { Amps }\end{array}$ & $\begin{array}{l}\text { Electrical } \\
\text { Loading } \\
\text { in Amps }\end{array}$ & $\begin{array}{l}\text { \% Efficiency } \\
\text { of DWM }\end{array}$ & $\begin{array}{l}\text { \% Efficiency of } \\
\text { DWSyRM }\end{array}$ & $\begin{array}{l}\text { Power } \\
\text { Factor of } \\
\text { DWM }\end{array}$ & $\begin{array}{l}\text { Power } \\
\text { Factor of } \\
\text { DWSyRM }\end{array}$ \\
\hline 1 & 4.5 & 4.0 & 90.9 & 78.6 & 0.91 & 0.97 \\
\hline 2 & 5.0 & 4.0 & 94.7 & 82.7 & 0.97 & 0.96 \\
\hline
\end{tabular}

From the detailed testing, characteristic curves are plotted for the various combinations of electrical and mechanical loads.

The following table shows the details of characteristic curves plotted for various combination of loading.

\begin{tabular}{|l|l|l|}
\hline S.No & Figure No(s) & Characteristics plotted \\
\hline 1 & $3,4,5$ & $\begin{array}{l}\text { Power factor, Efficiency and Torque } \\
\text { characteristics for mechanical load. }\end{array}$ \\
\hline 2 & $6,10,13,16$ & $\begin{array}{l}\text { Efficiency characteristics for } \\
\text { mechanical load with constant } \\
\text { electrical load. }\end{array}$ \\
\hline 3 & $7,11,14,17$ & $\begin{array}{l}\text { Torque characteristics for mechanical } \\
\text { load with constant electrical load. }\end{array}$ \\
\hline 4 & $8,9,12,15$ & $\begin{array}{l}\text { Power factor characteristics for } \\
\text { mechanical load with constant } \\
\text { electrical load. for the various }\end{array}$ \\
\hline 5 & 18 & $\begin{array}{l}\text { Efficiency comparison for the } \\
\text { electrical loads given }\end{array}$ \\
\hline 6 & $19-20$ & $\begin{array}{l}\text { Efficiency and Power factor } \\
\text { characteristics for the } \\
\text { mechanical and electrical load }\end{array}$ \\
\hline
\end{tabular}

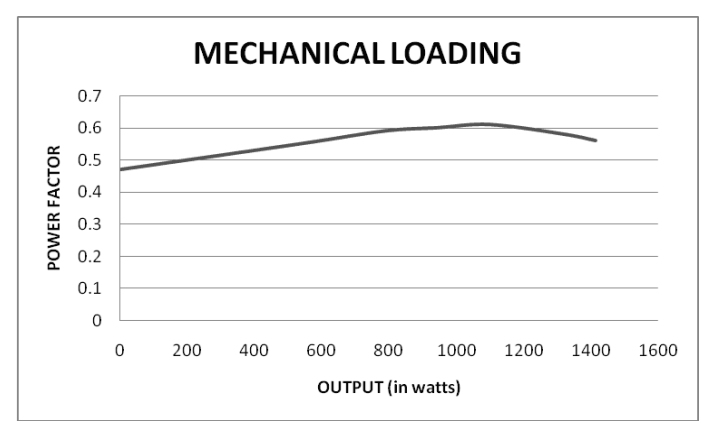

Figure3. Power Factor Characteristics

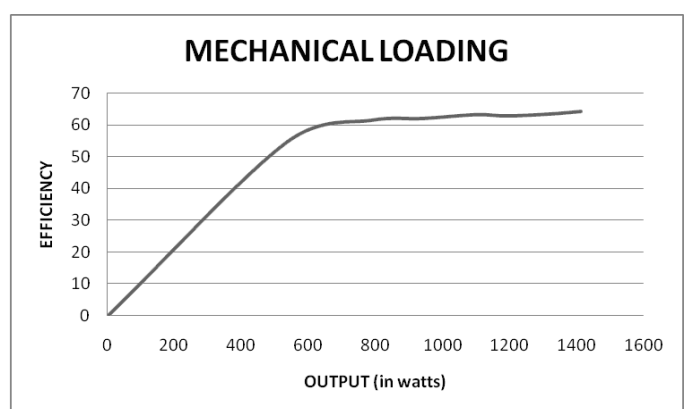

Figure4. Efficiency Characteristics

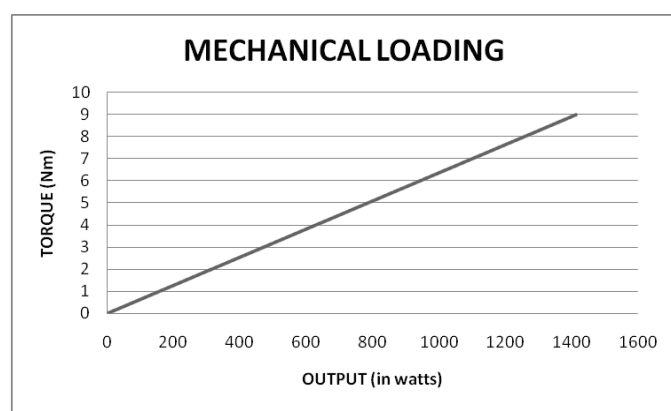

Figure5. Torque Characteristics

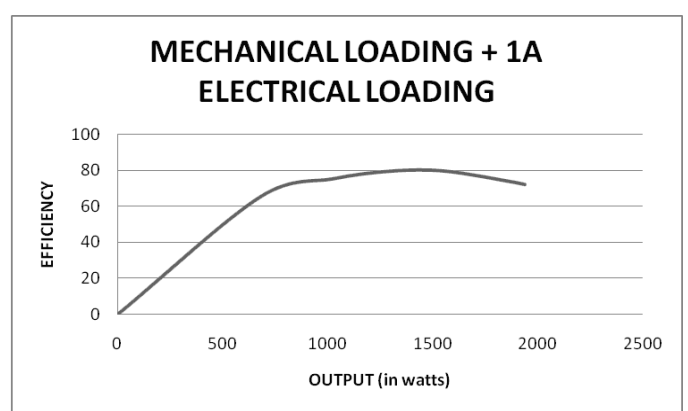

Figure6. Efficiency Characteristics with 1 A Eectrical load

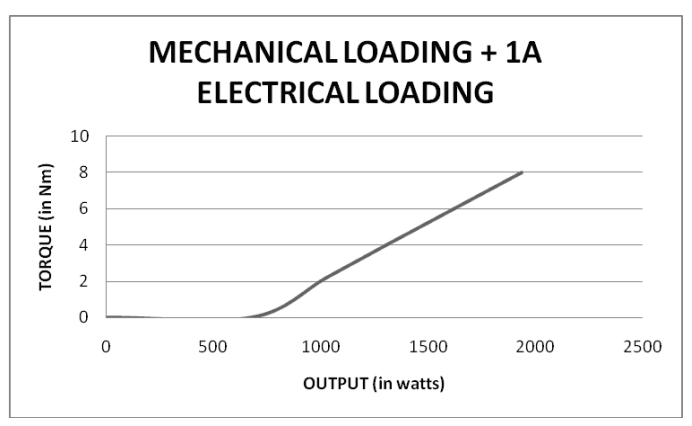

Figure7 Torque characteristics with 1A Electrical load

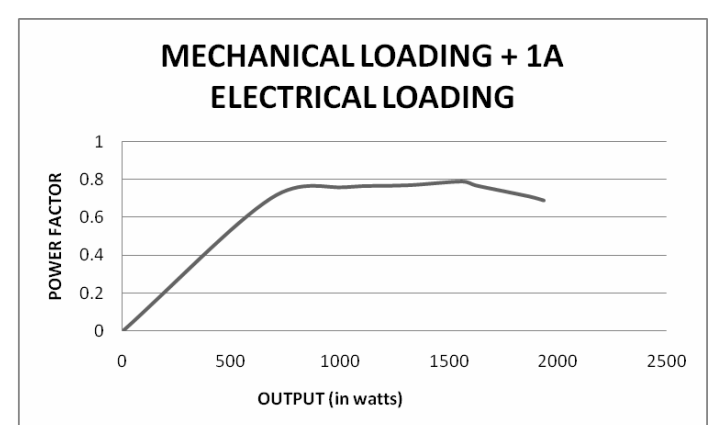

Figure8. Power Factor Characteristics with 1 A Electrical load 


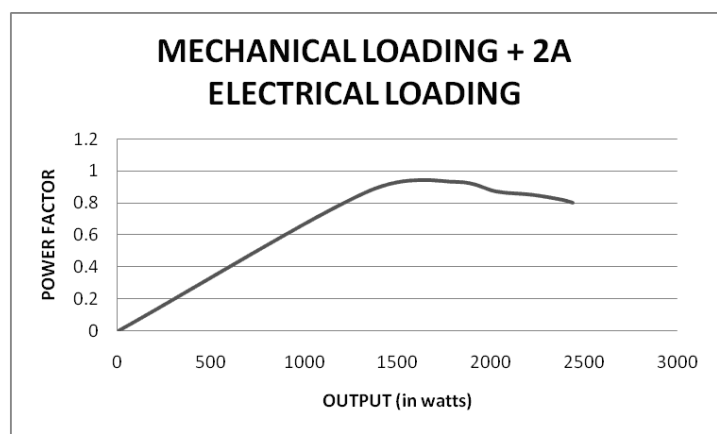

Figure 9. Power Factor Characteristics with 2 A Electrical load

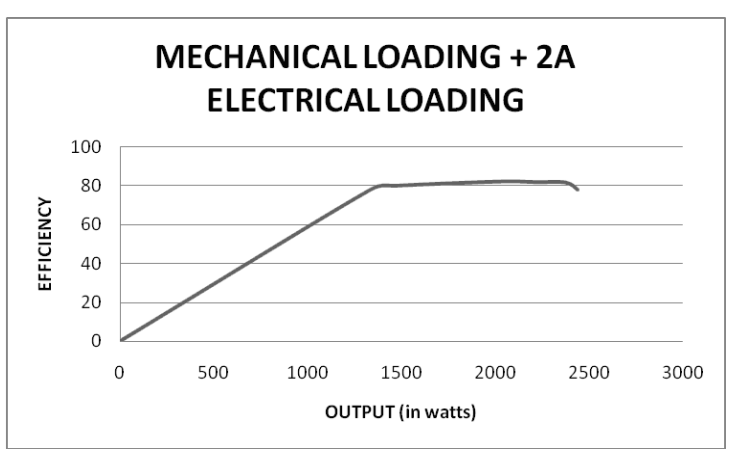

Figure10. Efficiency Characteristics with 2 A Electrical load

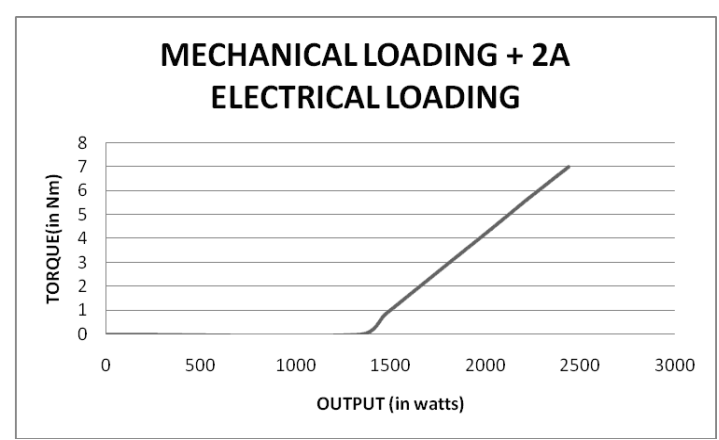

Figure11. Torque Characteristics with 2 A Eectrical load

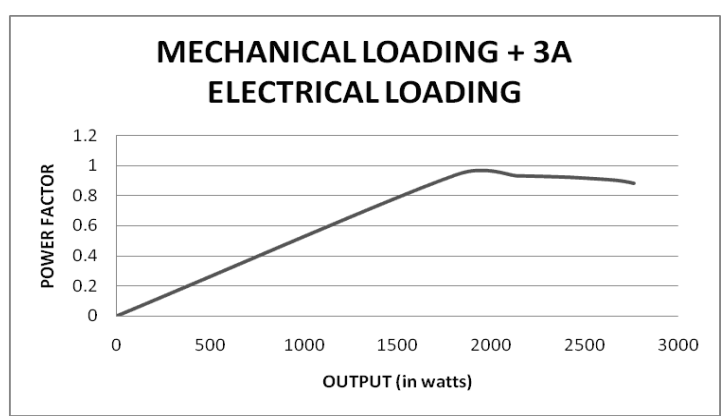

Figure 12 Power Factor Characteristics with 3 A Electrical load

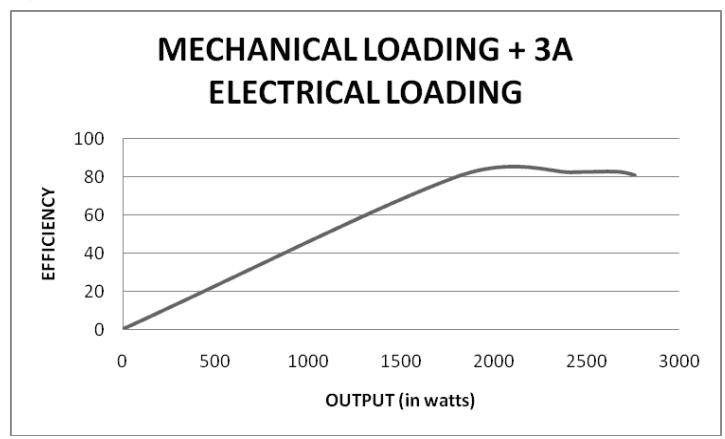

Figure13. Efficiency Characteristics with 3 A Electrical load

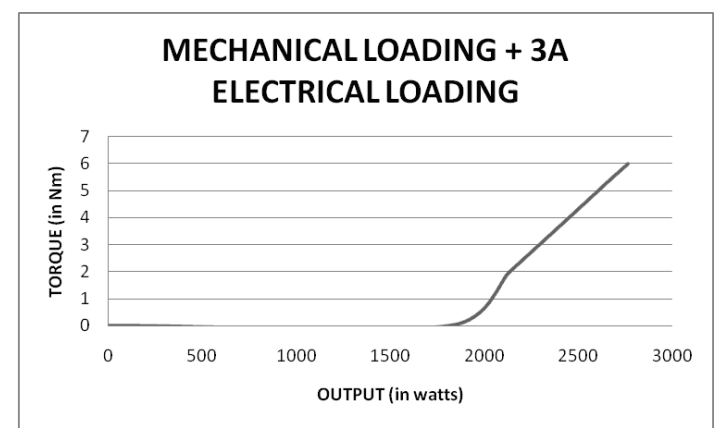

Figure14. Torque Characteristics with 3 A Electrical load

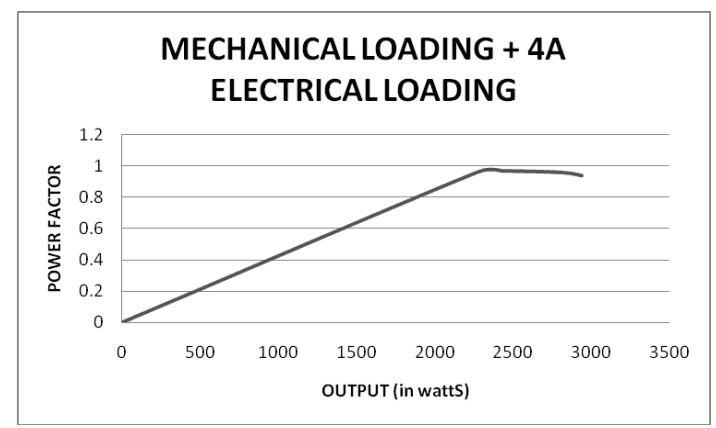

Figure15. Power Factor Characteristics with 4 A Electrical load

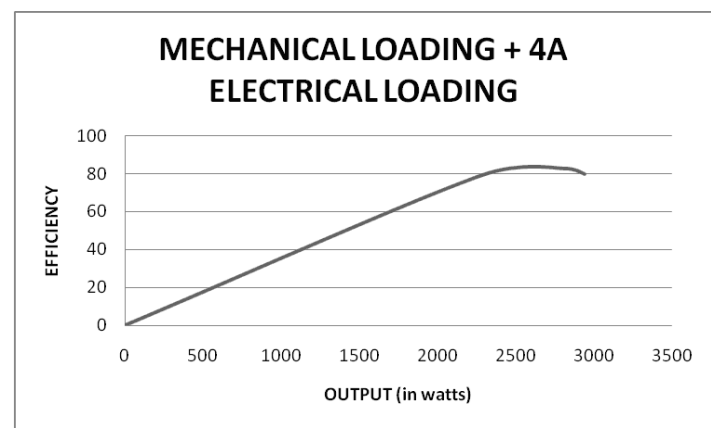

Figure16. Efficiency Characteristics with 4 A Electrical load

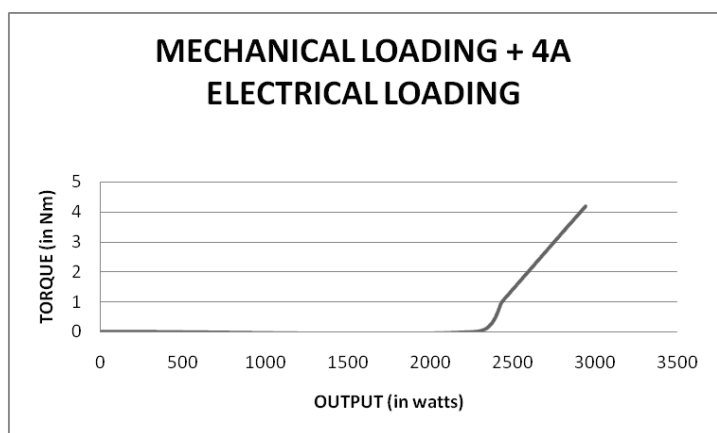

Figure17. Torque Characteristics with 4 A Eectrical load

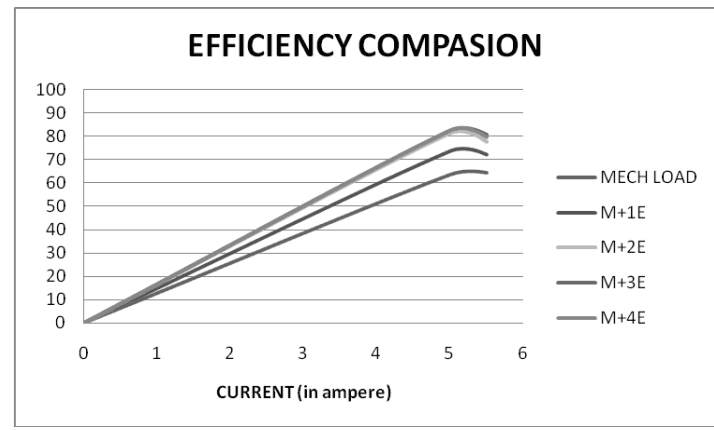

Figure18. Efficiency Comparison for various Electrical load 


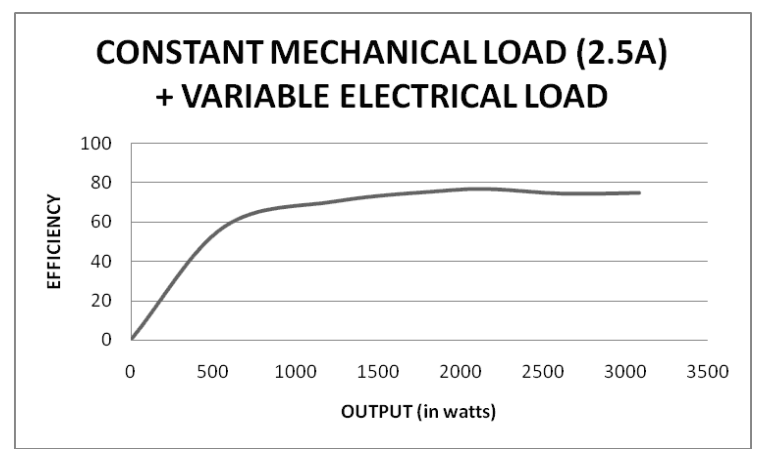

Figure19. Efficiency Characteristics for constant Mechanical load with 2.5 A Electrical load

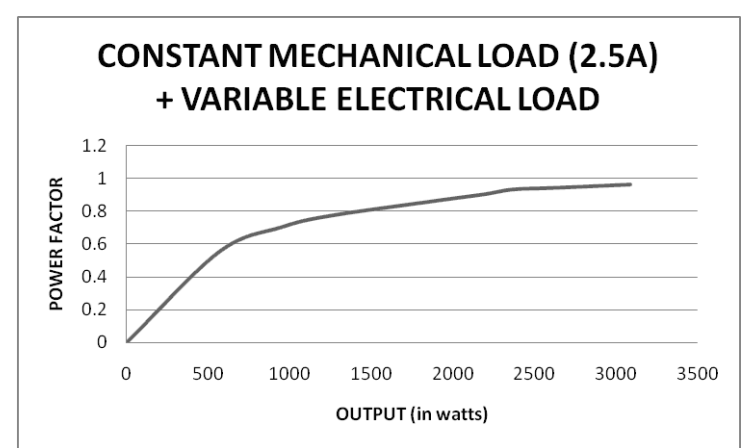

Figure20. Power Factor Characteristics for constant Mechanical load with 2.5 A Electrical load

\section{A. Energy Conservation}

The power factor and efficiency of reluctance motor ranges between 0.35 to 0.5 and $55 \%$ to $75 \%$ respectively. In the proposed DWSyRM machine, since two stator windings are provided, the machine can be operated as a motor and generator. By adjusting the electrical load in the second winding the power factor and efficiency are improved. The electrical load connected to the second winding is not depending on separate supply and hence energy conservation is possible in this type of machine.

\section{OBSERVATIONS AND ANALYSIS}

Out of two stator windings of DWSyRM, one set of winding is connected to a three phase supply, where the machine works as a Synchronous Reluctance Motor, while a three phase EMF is induced in the other set of winding and acts as an Induction Alternator. Table 1 refers to the reading observed during the conventional brake test considering only one set of winding, while other set of winding is left unconnected to any load. The maximum efficiency observed in this test is $64.2 \%$ and the maximum power factor is 0.56 for the load current of $5.5 \mathrm{~A}$. For the same load current, when electrical load is connected to the second set of winding, efficiency and power factor of the machine gradually improves. The details of improvement are presented in the Table X, it is observed that for the same load current of $5.5 \mathrm{~A}$, the efficiency and power factor are improved by $15.6 \%$ and 0.38 by the efficient operation of DWSyRM.
TABLE X. EFFICIENCY AND POWER FACTOR COMPARISON FOR THE LOAD CURRENT OF 5.5 A

\begin{tabular}{|l|l|l|l|l|}
\hline S.No & $\begin{array}{l}\text { Mech. } \\
\text { Load in } \\
\text { Amps }\end{array}$ & $\begin{array}{l}\text { Elec. } \\
\text { Load } \\
\text { in Amps }\end{array}$ & $\begin{array}{l}\text { Efficiency } \\
\text { In \% }\end{array}$ & $\begin{array}{l}\text { Power } \\
\text { factor }\end{array}$ \\
\hline 1 & 5.5 & - & 64.2 & 0.56 \\
\hline 2 & 5.5 & 1.0 & 72.2 & 0.69 \\
\hline 3 & 5.5 & 2.0 & 77.7 & 0.80 \\
\hline 4 & 5.5 & 3.0 & 80.7 & 0.88 \\
\hline 5 & 5.5 & 4.0 & 79.8 & 0.94 \\
\hline
\end{tabular}

The observed reading for the various combinations of electrical and mechanical load are shown in the Tables III $-\mathrm{V}$. Power factor, Efficiency and Torque characteristics for mechanical load test are shown in Figures3 - 5. Figures6 - 17 and $19-20$ shows the performance characteristics of the machine for the various combinations of electrical and mechanical load. Figure 18 shows the efficiency comparison for the various electrical loads on the second set of winding.

\section{CONCLUSION}

A $3 \mathrm{~kW}, 3$ - phase, 4- pole, $1500 \mathrm{rpm}, 415 \mathrm{~V}$ Double Winding Synchronous Reluctance motor has been designed and tested. When the machine is operated as conventional Synchronous reluctance motor, the maximum efficiency and power factor are $79.7 \%$ and 0.79 . When an electrical load is connected in the second winding, the efficiency and power factor are improved to $82.5 \%$ and 0.99 . By utilizing the electrical output from the second set of winding, dependency on separate supply to the connected load to this winding is reduced. The Double Winding Synchronous Reluctance Motor can be employed, where the induction motors run continuously like in textile industries and manufacturing units. The output power from the second winding can be used for charging the UPS system and supplying lighting loads.

\section{REFERENCES}

[1] C. Thanga Raj, S. P. Srivastava, Pramod Agarwal, "Energy Efficient Control of Three-Phase Induction Motor - A Review" International Journal of Computer and Electrical Engineering, Vol. 1, No. 1, April 2009, pp $61-70$

[2] Matsuo, T.; Lipo, T.A.; "Rotor design optimization of synchronous reluctance machine," IEEE Transactions on Energy Conversion, Vol.9 Issue:2, June 1994 pp 359 - 365

[3] F.Leonardi, T. Matsuo, and T. A. Lipo, "Iron loss calculation for synchronousreluctance machines," in Proc. 1996 Int. Conf. Power Electronics, Drives and Energy Systems for Industrial Growth, pp. 307-312.

[4] P.L. Alger, E.H.Freiburghouse and D.D.Chase, "Double windings for flexible alternators", AIEE Transactions, Vol.49, January 1930, pp 226 -244 .

[5] Alfredo Munaz-Garcia, Thomas A.Lipo, "Dual stator winding Induction Machine Drive", IEEE Transactions on Industry Applications Vol. 36, Sep/Oct 2000 pp 1369 - 1379

[6] Hubert.Razik, Abderrezak Rezzoug, Djafar. Hadiouche “ Modelling and Analysis of Dual - Stator Induction Motors", IEEJ Transcations Industrial Applications, Vol. 125, 2005 pp 1093-1104.

[7] J. E. Fletcher, B. W. Williams, and T. C. Green, "Efficiency aspects of vector control applied to synchronous reluctance motors," in Proc. IEEE/IAS Annu. Meet., vol. 1, 1995, pp 294-300.

[8] Harold J. Weber, "A.C. Induction motor energy conserving power control method and apparatus" US Patent 4806838, February 21, 1989.

[9] Grantham, C. Tabatanaei-Yazdi, H. Rahman,.F. "A novel method for rapid efficiency measurement of three phase induction motors" ,IEEE Transaction on Energy Conversion Dec1999, Vol. 14, pp 1236-1240. 
[10] Bhuvaneswari, R., Subramanian, S. (2005), "Optimization of three phase induction motor design using simulated annealing algorithm", Electric Power Components and Systems, Vol. 33, pp.947-56.

[11] Hyeoun-Dong Lee, Seog-Joo Kang, Seung-Ki Sul, “ Efficiency optimized direct torque control of synchronous reluctance motor using feedback linearization", Industrial Electronics, IEEE Transactions on Vol.46, Feb1999, pp 192-198.

[12] Heath Hofmann, Seth R. Sanders, "High-Speed Synchronous Reluctance Machine with Minimized Rotor Losses", IEEE Transactions on Industry Applications, Vol. 36, March/April 2000.

[13] Murakami Hiroshi, "Performance evaluation of Synchronous reluctance motor and the other motors with the same distributed winding and stator configuration" Transactions of the Institute of Electrical Engineers of Japan. D, Vol.120-D, pp 1068-1074 (2000).

[14] Heath F. Hofmann, Member, IEEE, Seth R. Sanders, Member, IEEE, and Ahmed EL-Antably, Member, IEEE, "Stator-Flux-Oriented Vector Control of Synchronous Reluctance Machines With Maximized Efficiency"IEEE Transactions On Industrial Electronics, Vol. 51, 2004 pp $1066-1072$.

[15] Nashiki Masayuki, Inoue, Yoshimity, Kawai Youichi, Takanori,Satake, Akiyoshi, Okuma, Shigeru, " Improvements of Power Factor and Torque of a Synchronous Reluctance Motor with a Slit Rotor" IEEJ Transactions on Industry Applications, 2006,Vol.126, pp. 116-123.

[16] E.S. Obe T. Senjyu "Analysis of a polyphase synchronous reluctance motor with two identical stator windings" Electric Power Systems Research Volume 76, Issues 6-7, April 2006, pp 515-524.

[17] Huann-Keng Chiang and Chih-Huang Tseng, "Design and implementation of a grey sliding mode controller for synchronous reluctance motor drive" Control Engineering Practice Vol. 12, February 2004, pp 155-163.

[18] S. Morimoto, M. Sanada,1and Y. Takeda, 8th International Conference on Power Electronics and Variable Speed Drives, "Optimum efficiency operation of synchronous reluctance motor without current sensor" London, UK, Sept. 2000, IEE Conf. Pub. / Volume 2000 / pp506-511.

[19] Chandrasekaran.V, Manigandan.T, " An Innovative Approach for Energy Conservation in Induction motor", International Conference on
Man-Machine Systems (ICoMMS), 11 - 13, October 2009, Batu Ferringhi, Penag, MALAYSIA, Pages IB2-1- IB2 - 6 .

[20] Lilibu, Chunhi, Jeffkrukowski, Wilsun Xu, Xian hiu, "A New Energy Recovery Double Winding Cage-Rotor Induction Machine" IEEE Transcations on Energy Conversion, Vol, 18,June 2002, pp315 - 320

Prof.V.Chandrasekaran, author of this paper born at Coimbatore in the year 1961. He graduated in the year 1990 in Electrical \& Electronics Engineering from Coimbatore Institute of Technology, Coimbatore and obtained post graduation in Electrical Machines in the year 1997. He is pursuing PhD programme with Anna University of Technology, Coimbatore. $\mathrm{He}$ has 20 years of experience in teaching. At present he is working as Professor and Head of the Department of Electrical and Electronics Engineering, Sri Krishna College of Engineering and Technology, Coimbatore. His major areas of interests are Electrical Machines, Control Systems and Electrical Drives.

He has thirst for energy conservation in induction machines. He has been working for design modifications and efficient operation of electrical machines for the past 10 years. He has presented technical papers in national and international conferences.

Dr.T.Manigandan co-author of this paper was born in the year 1968. He obtained his Bachelors degree and post graduate degree from Bharathiar University, Coimbatore. He obtained his $\mathrm{PhD}$ in Electrical Engineering from Anna University, Chennai.

He has more than 21 years of experience in teaching. At present he is working as Dean, School of Electrical Sciences, Kongu Engineering College, Erode.

His major areas of interests are Control Systems and Soft Computing. He has presented technical papers in seven International journals. Also he has presented 31 paper in National conferences and 23 papers in International conferences. He is currently guiding $10 \mathrm{PhD}$ scholars. 